\title{
ANALISIS INFEKSI Cowpea Mild Mottle Virus (CPMMV) TERHADAP TANAMAN KEDELAI Glycine max DENGAN MENGGUNAKAN UJI ELISA
}

\author{
As'ad Syamsul Arifin \\ Program Studi Pendidikan Biologi, IKIP Budi Utomo Malang. \\ Jalan Simpang Arjuno 14b Malang \\ Email: asad.ilem@yahoo.com
}

Penelitian ini bertujuan untuk menentukan positif terinfeksi CPMMV atau tidak yang dapat dilakukan dengan tes Uji Elisa yang dilaksanakan di Balai Penelitian Tanaman Jeruk dan Buah Subtropika (Balitjestro) terletak di desa Tlekung, Junrejo, Batu, Jawa Timur.

Jenis penelitian ini adalah penelitian eksperimen yang bertujuan untuk menganalisis dan memberikan informasi tentang tanaman kedelai yang positif terinfeksi CPMMV atau tidak, sampel varietas kedelai dalam penelitian ini meliputi Argopuro, gumitir, Anjasmoro, Mahameru, MLGG 0021 dan MLGG 0268 .

Hasil analisis dari setiap varietas yaitu Anjasmoro sakit A nilai absorban rata-rata 0.048, Anjasmoro sakit B nilai absorban rata-rata 0.051, Mahameru sakit A nilai absorban rata-rata 0.054 , Mahameru sakit B nilai absorban rata-rata 0.054 , Gumitir sakit A nilai absorban rata-rata 0.052 , Gumitir sakit B nilai absorban ratarata 0.061, MLGG 0021 sakit A nilai absorban rata-rata 0.016, MLGG 0021 sakit B nilai absorban rata-rata 0.059 , Argopuro sakit A nilai absorban rata-rata 0.059 , Argopuro sakit B nilai absorban rata-rata 0.055 , MLGG 0268 sakit A nilai absorban rata-rata 0.049 , dan MLGG 0268 sakit B nilai absorban rata-rata 0.047 . Dari variatas yang telah disebutkan serta berdasarkan hasil analisis Uji Elisa menunjukkan semua varietas positif terinfeksi virus CPMMV.

Kata kunci: Cowpea Mild Mottle Virus (CPMMV), Tanaman Kedelai, Uji ELISA.

\section{PENDAHULUAN}

Kedelai merupakan tanaman yang kaya protein nabati, karbohidrat dan lemak. Biji kedelai juga mengandung fosfor, besi, kalsium, vitamin B dengan komposisi asam amino lengkap, sehingga potensial untuk pertumbuhan tubuh manusia (Pringgohandoko dan Padmini, 1999). Kedelai juga mengandung asam-asam tak jenuh yang dapat mencegah timbulnya arteri sclerosis yaitu terjadinya pengerasan pembuluh nadi (Taufiq dan Novo, 2004).

Salah satu hambatan dalam meningkatkan produksi kedelai adalah adanya serangan hama. Serangga yang berasosiasi dengan tanaman kedelai di Indonesia telah diketahui sebanyak 266 jenis, yang terdiri atas 111 serangga hama, 53 
spesies serangga yang berstatus kurang penting, 61 jenis serangga predator, dan 41 jenis serangga parasit (Okada et al. 1988). Dari 111 serangga hama tersebut, 50 spesies di antaranya hama perusak daun, namun yang berstatus hama penting hanya sembilan jenis (Arifin dan Sunihardi 1997). Berdasarkan identifikasi dari sembilan jenis serangga hama pemakan daun, kutu kebul Bemisia tabaci adalah salah satu jenis hama yang sangat penting, karena di samping sebagai hama tanaman juga sebagai serangga hama pembawa virus. Tanaman kedelai yang terserang kutu kebul daunnya menjadi keriting. Apabila serangan parah disertai dengan infeksi virus, daun keriting berwarna hitam dan pertumbuhan tanaman terhambat. Ekskreta kutu kebul menghasilkan embun madu yang merupakan medium tumbuh cendawan jelaga, sehingga tanaman sering tampak berwarna hitam. Hal ini dapat menyebabkan proses fotosintesis pada tanaman kedelai tidak normal (Tengkano dan Suhardjan 1985). Kutu kebul mampu menularkan berbagai penyakit salah satunya virus CPMMV pada tanaman kedelai.
Tanaman kedelai yang tertular virus menyebabkan daun tanaman keriting mengecil, berwarna kekuningan, tanaman kerdil, dan polong tidak terbentuk. Kehilangan hasil akibat serangan hama kutu kebul dapat mencapai $80 \%$, bahkan dapat mengakibatkan gagal panen jika tidak dikendalikan. Tanaman kedelai yang biasanya ditanam oleh petani ditiap-tiap daerah seperti Probolinggo, Pasuruan dan Malang, banyak terserang beberapa penyakit, namun diantara petani masih belum mengetahui serangan virus pada tanaman kedelai, dan salah satunya virus CPMMV, virus CPMMV ini menginfeksi tanaman melewati kutu kebul, kutu inilah sebagai fektor perantara adanya infeksi virus. Sehingga peneliti tertarik untuk melakukan penelitian tentang Analisis Infeksi Cowpea Mild Mottle Virus (CPMMV) Terhadap Tanaman Kedelai Glycine Max Dengan Menggunakan Uji Elisa, dengan tujuan untuk menganalisis infeksi virus, guna memberikan informasi kepada para petani khususnya. 
BAHAN DAN METODE

Jenis penelitian ini adalah penelitian eksperimen. Rancangan penelitian yang digunakan adalah rancangan acak kelompok (RAK) yang bertujuan untuk menggambarkan dan mengumpulkan informasi tentang analisis infeksi virus (CPMMV) terhadap tanaman kedelai antara varietas yang terinfeksi dengan yang tidak terinfeksi.

Penelitian ini dilaksanakan di Balai Penelitian Tanaman Jeruk dan Buah Subtropika (Balitjestro) tempat Uji Elisa dan dilaksanakan di Balai Penelitian Tanaman Kacangkacangan dan Umbi-umbian (BALITKABI) Malang yaitu tempat penanaman tanaman kedelai.

Objek penelitian ini menggunakan enam macam varietas tanaman kedelai yaitu Argopuro, Gumitir, Anjasmoro, Mahameru, MLGG 0021 dan MLGG 0268.
Terdiri dari empat macam varietas tanaman kedelai berdaya hasil tinggi namun rentan terhadap serangan CPMMV yaitu Agropuro, Gumitir, Anjasmoro dan Mahameru, dan dua macam berikutnya genotip varietas kedelai yang tahan terhadap CPMMV yaitu MLGG 0021 dan MLGG 0268.

Analisis infeksi virus CPMMV dalam penelitian ini menggunakan Uji Elisa, tujuannya untuk mengetahui apakah tanaman kedelai sehat atau terserang CPMMV. Uji ELISA dalam penelitian ini menggunakan prosedur menurut Clark dan Adams (1976) seperti pada Gambar 1. 


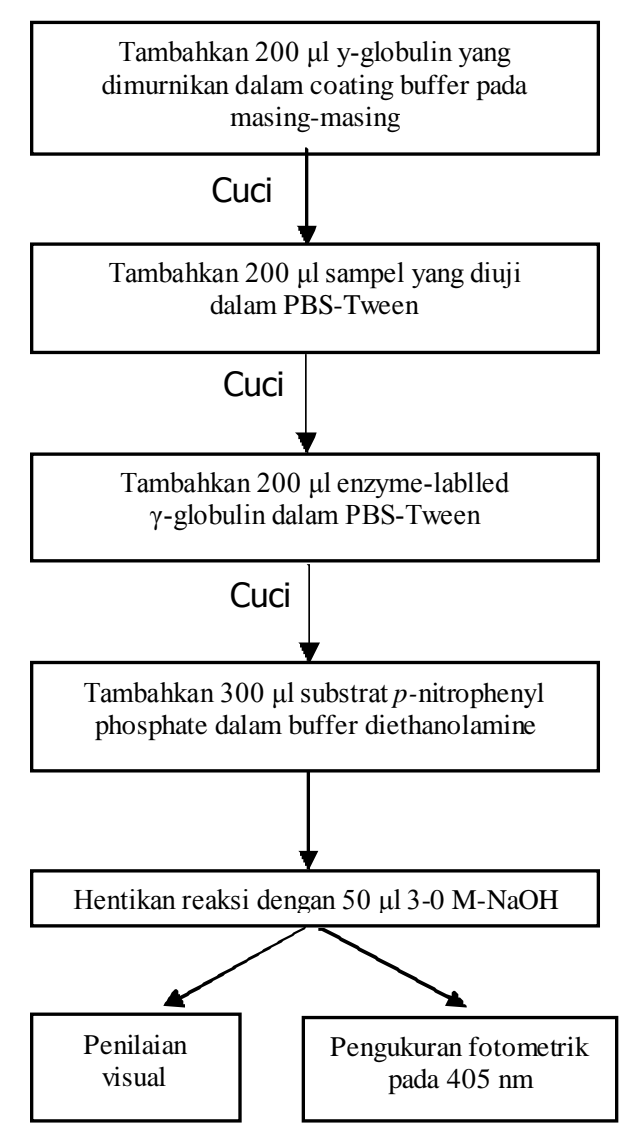

\section{HASIL DAN PEMBAHASAN}

Hasil Uji Elisa antara Kedelai Glycine max Sehat dengan Kedelai yang Terserang Cowpea Mild Mottle Virus (CPMMV) dapat dilihat pada Tabel 1. Data menunjukkan bahwa sampel nomer 1 negatif kontrol hasil nilai absorban rata-rata 0.003 hasil analisis menunjukkan negatif terinfeksi. Sedangkan sampel nomer 2 adalah positif kontrol hasil nilai absorban rata-rata 0.047 sehingga hasil analisis positif terinfeksi.

Tabel nomer 3 sampai nomer 14 secara berurutan adalah sampel varietas Anjasmoro sakit A nilai absorban rata-rata 0.048, Anjasmoro sakit B nilai absorban rata-rata 0.051 , Mahameru sakit A nilai absorban rata-rata 0.054, Mahameru sakit $\mathrm{B}$ nilai absorban rata-rata 0.054 , Gumitir sakit A nilai absorban ratarata 0.052, Gumitir sakit B nilai absorban rata-rata 0.061, MLGG 0021 sakit A nilai absorban rata-rata 0.016, MLGG 0021 sakit B nilai absorban rata-rata 0.059, Argopuro sakit A nilai absorban rata-rata 0.059, Argopuro sakit B nilai absorban rata-rata 0.055 , MLGG 0268 sakit A nilai absorban rata-rata 0.049, dan MLGG 0268 sakit B nilai absorban rata-rata 0.047. Dari variatas yang telah disebutkan serta berdasarkan hasil analisis Uji Elisa menunjukkan semua varietas positif terinfeksi virus CPMMV.

Tabel nomer 15 sampai nomer 26 secara berurutan adalah sampel varietas Gumitir sehat A nilai absorban rata-rata 0.009 , Gumitir sehat $B$ nilai absorban rata-rata 0.001, Anjasmoro sehat A nilai absorban rata-rata 0.001, Anjasmoro sehat $B$ nilai absorban rata-rata 0.005, Mahameru sehat A nilai absorban rata-rata 0.002, Mahameru 
sehat $\mathrm{B}$ nilai absorban rata-rata 0.003, MLGG 0268 sehat A nilai absorban rata-rata 0.002 , MLGG 0268 sehat $\mathrm{B}$ nilai absorban rata-rata 0.002, Argopuro sehat A nilai absorban rata-rata 0.005, Argopuro sehat B nilai absorban rata-rata 0.007, MLGG 0021 sehat A nilai absorban rata-rata 0.006 dan MLGG 0021 sehat $\mathrm{B}$ nilai absorban rata-rata 0.003. Dari variatas yang telah disebutkan serta berdasarkan hasil analisis Uji Elisa menunjukkan semua varietas negatif terinfeksi virus CPMMV.

Tabel 1. Hasil Uji Elisa

\begin{tabular}{|c|l|c|c|}
\hline No & \multicolumn{1}{|c|}{ Sampel } & Absorban rata-rata & Hasil analisis \\
\hline 1 & Negatif kontrol & 0.003 & - \\
\hline 2 & Positif kontrol & 0.047 & + \\
\hline 3 & Anjasmoro sakit A & 0.048 & + \\
\hline 4 & Anjasmoro sakit B & 0.051 & + \\
\hline 5 & Mahameru sakit A & 0.054 & + \\
\hline 6 & Mahameru sakit B & 0.054 & + \\
\hline 7 & Gumitir sakit A & 0.052 & + \\
\hline 8 & Gumitir sakit B & 0.061 & + \\
\hline 9 & MLGG 0021 sakit A & 0.016 & + \\
\hline 10 & MLGG 0021 sakit B & 0.059 & + \\
\hline 11 & Argopuro sakit A & 0.059 & + \\
\hline 12 & Argopuro sakit B & 0.055 & - \\
\hline 13 & MLGG 0268 sakit A & 0.049 & - \\
\hline 14 & MLGG 0268 sakit B & 0.047 & - \\
\hline 15 & Gumitir sehat A & 0.009 & - \\
\hline 16 & Gumitir sehat B & 0.001 & - \\
\hline 17 & Anjasmoro sehat A & 0.001 & - \\
\hline 18 & Anjasmoro sehat B & 0.005 & - \\
\hline 19 & Mahameru sehat A & 0.002 & - \\
\hline 20 & Mahameru sehat B & 0.003 & - \\
\hline 21 & MLGG 0268 sehat A & 0.002 & - \\
\hline 22 & MLGG 0268 sehat B & 0.002 & + \\
\hline 23 & Argopuro sehat A & 0.005 & + \\
\hline 24 & Argopuro sehat B & 0.007 & + \\
\hline 25 & MLGG 0021 sehat A & 0.006 & + \\
\hline 26 & MLGG 0021 sehat B & 0.003 & + \\
\hline & & & + \\
\hline
\end{tabular}

Tanaman yang sehat merupakan tanaman yang tidak mengalami penyimpangan, baik organ-organ maupun bagian-bagian tubuh tanaman, termasuk terhenti dan terganggunya jalan dari fungsi- 
fungsi vital atau terjadi penyimpangan kesehatannya dari keadaan normal, yang mempunyai akibat yang merugikan bagi tanaman tersebut, jadi disini tanaman hanya ditinjau sebagai makhluk hidup.

Menurut Stackman dan Harrar (1968), tanaman yang sehat merupakan tanaman yang tidak mengalami penyimpangan yang tegas, tetap atau permanen dari pertumbuhan dan struktur yang normal pada tanaman, hingga tidak menimbulkan gejala yang dapat dilihat, yang tidak merugikan terhadap mutu dan tidak menurunkan nilai ekonomi dari tanaman tersebut. Disini Stackman telah memasukkan unsur ekonomi dari tanaman, dimana tanaman yang sehat tidak akan menurunkan nilai ekonomi dari tanaman yang kita tanam.

Walker (1991) mengatakan bahwa, tanaman yang dikatakan sakit itu dapat dibedakan dengan tanaman yang sehat, disebabkan terjadinya perubahan susunan atau proses "fisiologis" yang dapat disebabkan oleh salah satu faktor atau penyebab lingkungan yang tidak cocok, atau oleh satu atau beberapa dari sekian banyak faktor penyebab. Tanaman

dikatakan sakit apabila ukuran tanaman yang terinveksi lebih kecil bila dibandingkan dengan tanaman normal. Contohnya pada tanaman kedelai yang terserang CPMMV (cowpea mild mottle virus). Mosaik menunjukkan adanya warna yang berbeda secara tidak teratur, seperti warna hijau tua yang diselingi dengan hijau muda. Gejala mosaic biasanya didahului oleh pemucatan sepanjang tulang daun (vein clearing) atau akumulasi warna hijau sepanjang tulang daun (vein banding).

CPMMV telah menginfeksi hampir semua pertanaman kedelai di Jawa Timur dengan tingkat infeksi mencapai 100\% (Baliadi dan Saleh, 1993). CPMMV terus berkembang sejalan dengan meningkatnya populasi hama kutu kebul yang menjadi serangga vektor CPMMV di lapangan (Baliadi dan Saleh, 1993). Vektor akan melakukan pelukaan sel tanaman. Virus CPMMV merupakan patogen luka. Virus masuk ke dalam sitoplasma sel tanaman apabila terjadi pelukaan yang menembus dinding sel tanaman. Setelah masuk ke bagian tanaman tertentu, CPMMV dapat menyerang tanaman secara 
sistemik dengan cara tersebar ke selsel tanaman lainnya melalui plasmodesmata. Virus juga dapat berpindah pada sel-sel yang jauh dari daerah awal terjadi perlukaan melalui sistem pembuluh tanaman, terutama melalui floem (Akin, 2003).

\section{KESIMPULAN}

Tanaman kedelai yang terinfeksi virus CPMMV akan menyebabkan daun tanaman keriting mengecil, berwarna kekuningan, tanaman kerdil, dan polong tidak terbentuk dan kehilangan hasil akibat serangan hama kutu kebul, kutu kebul adalah jenis serangga sebagai fektor proses awal terjadinya infeksi virus.

Hasil analisis dari setiap varietas yaitu Anjasmoro sakit A nilai absorban rata-rata 0.048 , Anjasmoro sakit B nilai absorban rata-rata 0.051, Mahameru sakit A nilai absorban rata-rata 0.054 , Mahameru sakit B nilai absorban rata-rata 0.054 , Gumitir sakit A nilai absorban rata-rata 0.052 , Gumitir sakit B nilai absorban rata-rata 0.061 , MLGG 0021 sakit A nilai absorban rata-rata 0.016, MLGG 0021 sakit B nilai absorban rata-rata 0.059 ,
Argopuro sakit A nilai absorban ratarata 0.059, Argopuro sakit B nilai absorban rata-rata 0.055 , MLGG 0268 sakit A nilai absorban rata-rata 0.049, dan MLGG 0268 sakit B nilai absorban rata-rata 0.047. Dari variatas yang telah disebutkan serta berdasarkan hasil analisis Uji Elisa menunjukkan semua varietas positif terinfeksi virus CPMMV.

\section{SARAN}

Penelitian ini dapat dilakukan dan dikembangkan pada tanaman kacang-kacangan yang lainnya, dengan menggunakan jenis varietas yang lain.

\section{DAFTAR PUSTAKA}

Akin, H.M. 2003. Respon Beberapa Genotip Kedelai terhadap Infeksi CPMMV. J. Hama dan Penyakit Tropika Tumbuhan. 3(2).

Arifin. M. dan Sunihardi. 1997. Biopestisida SNPV untuk mengendalikan ulat grayak Spodoptera litura. Warta Penelitian dan Pengembangan Pertanian.14(528):1-16.

Baliadi, Saleh. 2006. Penyakit Cowpea Mild Mottle Virus Pada Kedelai Dan Strategi Pengendaliannya. Bul. Palawija. 11:7-14.

Okada, T., W. Tengkano, dan T. Djuarso. 1988. An outline of soybean pest in indonesia in faunistic aspects. Seminar 
Balittan Bogor, 6 Desember1988.

Pringgohandoko, B. dan O.S. Padmini 1999. Pengaruh Rhizo-plus dan Pemberian Cekaman Air Selama Stadia Reproduksi terhadap Hasildan Kualitas Biji Kedelai. Agrivet Vol 1.

Stackman, H. 1986. Chemosensory bases of host plant selection. Ann. Rev. Entomol. 31:115136

Taufiq, T.M.M. dan I. Novo. 2004. Kedelai, Kacang Hijau dan
Kacang Panjang. Absolut Press. Yogyakarta.

Tengkano, W., dan M. Suhardjan 1985. Jenis hama utama pada berbagai fase pertumbuhan tanaman kedelai. Dalam S. Sadikin, S., M. Ismunadji, Sumarno, M. Syam, S.O. Manurung, Yuswadi (Eds.). Kedelai. Puslitbangtan, Bogor. p. 295318.

Walker. 1991. Influince of Wheat Straw Mulch and Matalachlor on Corn Growth and Yield. 42:141-147. 